\title{
Vila Z. D. Costi: \\ a história e a arquitetura \\ resultante de um grupo \\ de moradias operárias \\ em Passo Fundo
}

\author{
Pedro Henrique Carretta Diniz, \\ Caliane Christie Oliveira de Almeida*
}

\begin{abstract}
Resumo Este artigo trata do processo de implantação do Frigorífico Z. D. Costi e sua vila operária (1948 - 1959), localizados em Passo Fundo/RS, observando a inserção urbana e a arquitetura resultante no conjunto de moradias. Quanto aos procedimentos metodológicos, a pesquisa foi desenvolvida em três principais etapas: pesquisa bibliográfica, documental e em campo, na qual foram ouvidos os relatos de três antigos funcionários da fábrica a fim de complementar as análises propostas. Espera-se que este artigo corrobore para o conhecimento da história da habitação operária no Rio Grande do Sul, destacando a importância do mencionado complexo frigorífico para a conformação do parque habitacional em Passo Fundo, bem como contribua para o debate em torno do tema em cidades de porte médio.
\end{abstract}

Palavras-chave: vila operária, Vila Z. D. Costi, Passo Fundo/RS.

Vila Z. D. Costi: la historia y la arquitectura resultante de un grupo de casas de trabajadores en Passo Fundo

\begin{abstract}
Resumen Este artículo trata del proceso de implementación del Frigorífico Z. D. Costi y su villa obrera (1948 - 1959), ubicada en Passo Fundo/RS, observando su inserción urbana y la arquitectura resultante. En cuanto a los procedimientos metodológicos, el artículo se desarrolló en tres etapas principales: investigación bibliográfica, documental y de campo, cuando se escucharon los informes de tres ex empleados de la fábrica con el fin de complementar los análisis propuestos. Se espera que este artículo corrobore para el conocimiento de la historia de las villas obreras en Rio Grande do Sul, destacando la importancia del mencionado complejo frigorífico en la conformación del parque habitacional en Passo Fundo, además de contribuir al debate en ciudades de tamaño medio.
\end{abstract}

Palabras clave: villas obreras, Vila Z. D. Costi, Passo Fundo/RS.
Vila Z. D. Costi: the history and the resulting architecture of a group of workers' houses in Passo Fundo

\begin{abstract}
This paper presents the process of implantation of Frigorífico Z. D. Costi and its worker's village (1948 - 1959), located in Passo Fundo/RS, observing its urban insertion and the resulting architecture. Regarding the methodological procedures, the article was developed in three main stages: bibliographic, documentary and on-site research, when the reports of three former employees of the factory were heard in order to complement the proposed analyzes. It is hoped that this paper corroborates for the knowledge of the history of workers' villages in Rio Grande do Sul, highlighting the importance of the mentioned industrial complex for the formation of the housing stock in Passo Fundo, as well as contributing to the debate around the theme in medium-sized cities.
\end{abstract}

Keywords: workers' villages, Vila Z. D. Costi, Passo Fundo/RS. 
uitos bairros e cidades brasileiras tiveram sua gênese ou se desenvolveram a partir da construção de agrupamentos habitacionais por parte de industriais, donos de fábricas e rentistas, sobremaneira entre o fim do século XIX e a primeira metade do século XX1 . Esse processo é tido por diversos autores, a citar Blay (1985), Chalhoub (1996), Correia (1998), Gunn e Correia (2005) e Timm (2015), como um dos fenômenos derivados da urbanização de nossas cidades, e possui relação com a necessidade de retenção de mão de obra advinda do meio rural em busca de trabalho nas fábricas que se instalavam nos centros urbanos à época. A importância do estudo desses agrupamentos está ligada à sua representatividade, no que diz respeito ao montante de unidades construídas, aos programas e tipologias habitacionais concebidas, assim como ao impacto na organização social e urbana das regiões onde foram implantados os conjuntos, conforme destacado por Correia (2013).

Em relação ao vocabulário especializado, podem ser encontradas diferentes nomenclaturas para conceituar os agrupamentos habitacionais construídos pela iniciativa privada no Brasil. As "vilas operárias", mais especificamente, são consideradas conjuntos urbanos, dotados ou não de equipamentos sociais, compostos por moradias unifamiliares geralmente dispostas de forma linear ao longo de uma ou mais vias, remetendo ao esquema de produção seriada das fábricas e indústrias (CORREIA, 2001; TIMM, 2015). Segundo Almeida (2012), as vilas operárias eram comumente denominadas de "vilas higiênicas" até a década de 1940, período em que essa forma de organização se consolidou como resposta, essencialmente, à falta de ordem, higiene e decência, características mormente atribuídas àqueles que residiam em moradias proletárias. Outra denominação comumente encontrada é a de "núcleos fabris", utilizada para descrever conjuntos habitacionais isolados dos centros urbanos, de dimensões mais reduzidas, onde os donos das fábricas detêm monopólio sobre a propriedade imobiliária (CORREIA, 2001).

Observando a dimensão continental do território brasileiro e a pluralidade cultural e socioeconômica da população, estudar tais agrupamentos habitacionais e os seus aspectos arquitetônicos e urbanísticos se torna uma atividade complexa. Diante desse contexto, valem ser registradas as contribuições de Almeida (2007/2012), Blay (1985), Borba (1994), Chalhoub (1996), Correia (1998), Guazzelli (2014), Gunn e Correia (2005), Heredia (2003), Janke (1999/2009), Jeronymo (2012), Miranda (2013), Moreira

* Pedro Henrique Carretta Diniz é Arquiteto e Urbanista, Mestrando no Programa de Pós-Graduação Stricto Sensu em Arquitetura e Urbanismo da Faculdade Meridional IMED, ORCID <https://orcid. org/0000-0001-6726-3380>. Caliane Christie Oliveira de Almeida é Arquiteta e Urbanista, Professora da Faculdade Meridional IMED, ORCID <https://orcid. org/0000-0002-8477-389X>.
(2002), Paulitsch (2003), Rago (1985), Sampaio (2002), Timm (2015), Varon (1998), Vianna (2006/2012) e muitos outros, que possuem relevância, principalmente, no que diz respeito ao resgate da história da moradia operária e sua importância na formação de muitas cidades em nosso país. Em linhas gerais, os mencionados autores concentram suas análises em cidades de grande porte, destacando o vocabulário arquitetônico de referência e/ou o processo de monte e desmonte das fábricas e conjuntos residenciais, ficando as cidades de médio porte - a exemplo de Passo Fundo, localizada ao noroeste sul-rio-grandense -, e as análises de projeto arquitetônico e urbanístico em segundo plano. 
1 Um importante exemplo de cidade que teve sua gênese atrelada à construção de um núcleo fabril é Caieiras (SP), construída pela Companhia Melhoramentos S/A em fins do século XIX, e emancipada em 1958 tamanha dimensão e autonomia local que assumiu (JERONYMO, 2012).
Ressalta-se, ainda, a escassez de trabalhos específicos acerca das vilas operárias da cidade de Passo Fundo. A historiografia local conta com referências pontuais, e baseadas mormente na história oral, sobre o movimento operário e a criação e atuação de algumas fábricas e frigoríficos da região, a exemplo dos trabalhos de Costi e Ribeiro (2003), Tedesco et. al (2005) e Tedesco e Souza (2016). O supramencionado quadro se coloca como justificativa e destaca a importância da elaboração deste artigo.

A problemática que balizou o desenvolvimento desta pesquisa envolve a não identificação ou reconhecimento da produção habitacional voltada ao operariado como parte integrante do patrimônio industrial e da paisagem cultural da cidade de Passo Fundo e, consequentemente, da sua história. Nessa perspectiva, a especulação imobiliária, aliada ao processo de verticalização da cidade - intensificado a partir da década de 1990 (FERRETTO, 2012) - e às mudanças socioespaciais ocorridas ao longo dos anos, contribuíram significativamente para que este patrimônio sofresse abandono, modificações e/ou uma significativa descaracterização, chegando ao extremo da demolição, como é o caso do Frigorífico Z. D. Costi e sua vila operária. Este objeto, especificamente, não foi sequer registrado iconograficamente pela historiografia local, e o seu valor histórico-cultural cedeu espaço para a construção de um shopping center de abrangência regional. Ademais, vale destacar que, em Passo Fundo, nenhum conjunto ou residência operária possui qualquer tipo de proteção legal.

Nesse sentido, o objetivo principal deste artigo é analisar o processo de implantação do Frigorífico Z. D. Costi, sobretudo das três etapas da sua vila operária, bem como a sua inserção urbana e a arquitetura resultante, com o intuito de registrar e analisar a importância deles para a conformação do parque habitacional do bairro passofundense São Cristóvão, a partir de meados do século XX.

Para tanto, foram realizados procedimentos de pesquisa bibliográfica, pesquisa documental e pesquisa em campo. Nesse sentido, vale destacar que este artigo de natureza qualitativa foi baseado, sobremaneira, em dados primários e oficiais (periódicos locais em circulação à época, documentos de aprovação, projetos arquitetônicos e urbanísticos do Frigorífico e da vila operária em questão, etc.), encontrados no amplo levantamento realizado no Arquivo Histórico Regional e no Instituto Histórico de Passo Fundo. Dentre os principais periódicos analisados, destaca-se o jornal independente O Nacional, fundado em 1925 e ainda em circulação na cidade. Ao todo, foram mais de 2.000 exemplares de periódicos levantados e analisados.

Acerca da pesquisa de campo, realizou-se visitas in loco e conversas informais com três antigos funcionários e moradores da referida vila operária. Os encontros tiveram duração média de 30 minutos, ocorreram de forma voluntária e sem ônus financeiro para nenhuma das partes, e foram antecedidos por esclarecimentos acerca da condução do processo de pesquisa e pela assinatura do Termo de Consentimento Livre e Esclarecido (TCLE). Com exceção do primeiro funcionário, que não permitiu a gravação, as outras duas conversas foram gravadas em formato MP3 (áudio). Além disso, o registro das informações também se deu por meio de anotações. Para preservar a identidade e a privacidade dos envolvidos, serão omitidos dos excertos de fala os nomes dos antigos funcionários. Desse modo, as citações ocorrerão da seguinte maneira: F1 (para as informações verbais obtidas em conversa com o funcionário de $n^{\circ} 1$ ); $F 2$ (para as informações verbais obtidas em conversa com o funcionário de $n^{\circ} 2$ ); e assim sucessivamente. 
Mais detalhadamente, marcou-se o primeiro encontro com o funcionário F1, um dos operários mais antigos da fábrica, que indicou o contato dos demais colegas. Essa etapa foi de suma importância para reconhecer as contribuições dos operários na construção da memória do Frigorífico Z. D. Costi e seu conjunto de moradias. Vale ressaltar que, em linhas gerais, os trabalhos que abordam a história da fábrica e do bairro São Cristóvão trazem apenas os relatos dos proprietários e seus herdeiros, não inserindo a dimensão dos funcionários e seus familiares em seus registros.

Sendo assim, espera-se que este artigo corrobore para o conhecimento da história da habitação voltada à classe operária em uma cidade de porte médio, localizada no interior do estado do Rio Grande do Sul, destacando a importância do Frigorífico Z. D. Costi e de sua vila operária para a conformação do parque habitacional na localidade, trazendo novos elementos para o debate sobre o assunto, contribuindo para a rememoração da história da cidade e do bairro São Cristóvão, e trazendo novos subsídios para o reconhecimento do valor patrimonial das antigas fábricas e vilas operárias de Passo Fundo.

\section{Frigorífico Z. D. Costi: história e pioneirismo}

Tal como ocorreu em diversas outras cidades do Brasil, os últimos anos da década de 1940 marcaram o início de um período de grande desenvolvimento econômico em Passo Fundo. Nos anos subsequentes, após a elaboração do primeiro Plano de Ordenamento e Expansão da cidade, datado de 1953 e outorgado em 1957, a então Avenida Mauá e o Bairro São Cristóvão, na região sudeste da cidade, se tornaram vetores de crescimento urbano, propiciando a instalação de grandes fábricas (GOSCH, 2002), a citar: as Indústrias Planaltina S/A; a Semeato; a Fábrica da Pepsi Cola; e a Fábrica de Refrigerantes Irmãos Bernardon. O Frigorífico Z. D. Costi, por sua vez, foi precursor neste processo, sendo considerado a primeira fábrica de grande porte a ser instalada no referido bairro (MENÇÃO..., 1979).

Zeferino Demétrio Costi, fundador do Frigorífico Z. D. Costi, foi agricultor, bancário, comerciante e diretor da Costi S/A - Indústria e Comércio, empresa de sua família na cidade de Encantado/RS, onde também foi prefeito entre os anos de 1936 e 1938. Uma década depois, tendo larga experiência na fabricação de produtos de origem pecuária, decidiu se instalar em Passo Fundo e inaugurar sua própria fábrica, em novembro de 1948 (MENÇÃO..., 1979).

A gleba onde foi construído o Frigorífico estava localizada na antiga Vila Exposição (atualmente Bairro São Cristóvão), às margens da Avenida Mauá, atualmente conhecida como Avenida Presidente Vargas (TEDESCO et. al., 2005) (Figura 1). Entretanto, em fins da década de 1940, o bairro São Cristóvão ainda estava se consolidando e a própria avenida, tão importante para o desenvolvimento da região sudeste de Passo Fundo, ainda estava sendo ampliada e pavimentada.

Para além da carência de infraestrutura e serviços na localidade, a instalação do Frigorífico Z. D. Costi implicou na superação de outro obstáculo: a escassez de mão de obra. Nas palavras de Costi e Ribeiro (2003), muitos dos funcionários foram trazidos do campo para a cidade ainda jovens, sendo necessário fixá-los perto da fábrica porque não havia transporte para a cidade à época. Os relatos do ex-funcionário F1 (2018), 


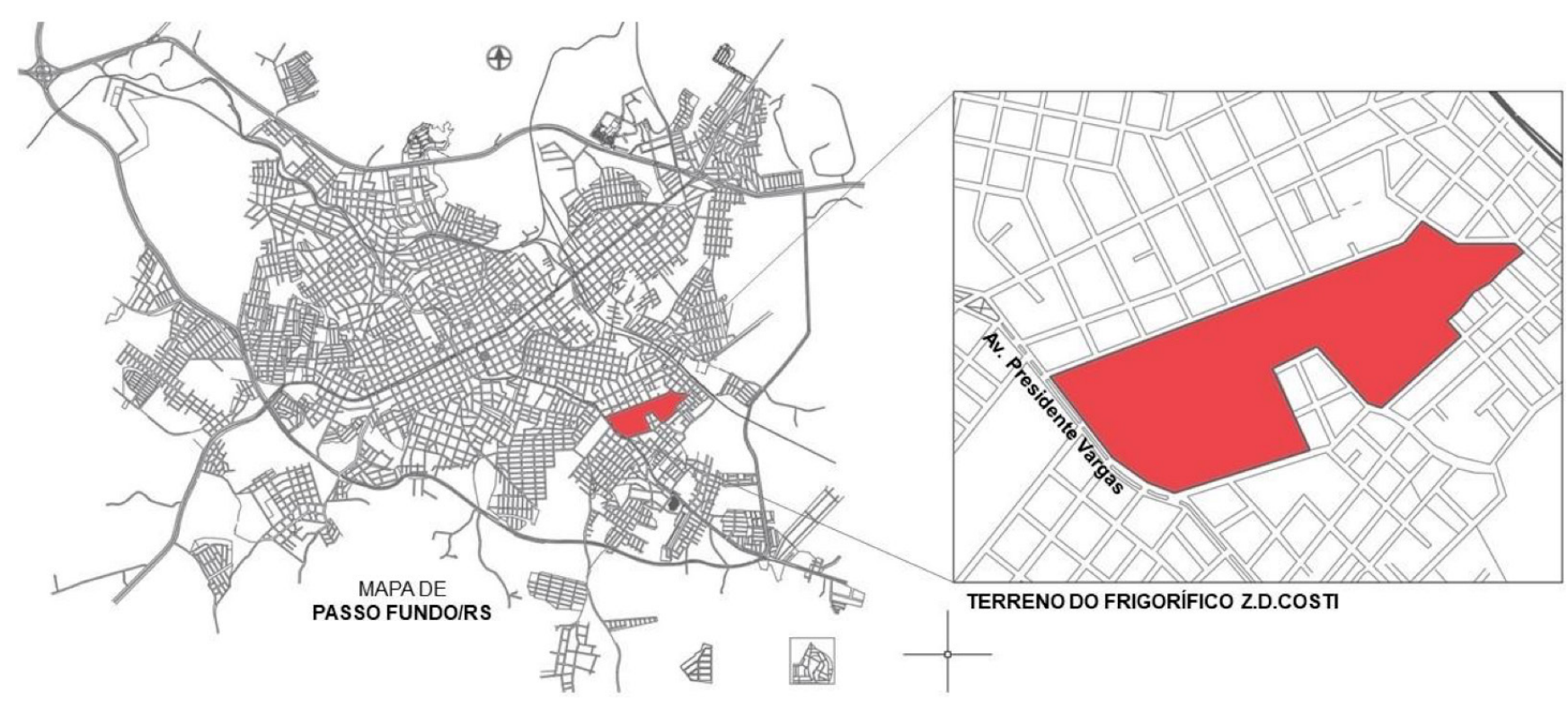

Figura 1: Mapa de localização do Frigorífico Z. D.Costi em Passo Fundo (sem escala). Fonte: autores, tendo como base cartográfica o mapa de Prefeitura de Passo Fundo (2018).

2 Conversa informal com o funcionário $\mathrm{F} 1$, realizada pelo autor. Passo Fundo, out. 2018. corroboram com essa informação. Segundo ele, dois anos antes da inauguração da fábrica, em 1946, o Sr. Costi e sua esposa, Sra. Alice Costi, foram ao Distrito de São Roque, localizado a $10 \mathrm{~km}$ de Passo Fundo, em busca de pedras e operários. Na ocasião, ele foi convidado a se mudar para Passo Fundo, e se instalar em uma casa nas proximidades de onde estava sendo construído o matadouro, para ajudar na construção dos demais prédios fabris. Ele trabalhou na construção e, posteriormente, no setor de desossa, até meados da década de 1950, quando se desligou do frigorífico. A casa onde ele residiu até então, estava localizada ao lado esquerdo da fábrica, na primeira das três etapas da vila operária (informação verbal)²; como se verá mais detalhadamente a seguir.

Seguindo a tendência observada em inúmeras localidades do país, os empresários da família Costi perceberam a necessidade de fixar os operários que estavam chegando da zona rural e não possuíam moradia, ainda nos primeiros anos da implantação da fábrica. Era preciso ensinar-Ihes um novo ofício, pois, grande parte deles cresceu no campo, possuía estreita relação com as atividades agrícolas e raramente havia trabalhado no setor frigorífico, evidenciando a falta de mão-de-obra qualificada em Passo Fundo naquele período. Havia também a necessidade de mantê-los por perto, proporcionando-lhes melhores condições de vida e, assim, produzindo e gerando mais lucro para a empresa, como destacado nas conversas informais realizadas e na bibliografia consultada. Dessa maneira, entre os anos de 1948 e 1959, as três etapas da Vila Z. D. Costi foram construídas, totalizando em torno de 115 casas.

Em relação à implantação da estrutura fabril, a entrada principal do Frigorífico Z. D. Costi se dava pela então chamada Avenida Mauá, por meio de uma edificação 
3 Anteriormente, o prédio em questão funcionava como um grande depósito de móveis (COSTI; RIBEIRO, 2003).

Figura 2: Fachada do pavilhão principal do Frigorífico Z. D. Costi $(\mathrm{s} / \mathrm{d})$, onde pode-se observar a marcação do acesso e o emprego de platibandas, tijolos aparentes e poucos elementos decorativos. Fonte: Arquivo Histórico Regional de Passo Fundo (2018).

Figura 3: Foto aérea do Frigorífico Z. D. Costi (1970), por meio da qual pode-se observar os prédios fabris em primeiro plano e as três etapas da vila operária à esquerda e aos fundos, como assinalado. Fonte: Instituto Histórico de Passo Fundo (2020), manipulação própria. pré-existente de alvenaria ${ }^{3}$, que foi refuncionalizada para o novo uso (Figura 2 e 3). A volumetria resultante das primeiras edificações do frigorífico remetia à estética fabril, com características comuns às construções erguidas por donos de fábricas e industriais no Brasil, sobretudo nas primeiras décadas do século XX, fundamentada em noções de economia, eficiência, utilidade e funcionalidade, conforme colocado por Correia (2014). O pavilhão principal do Frigorífico Costi foi projetado praticamente sem elementos decorativos, com embasamento em pedra, paredes externas com tijolos aparentes, esquadrias de ferro e coroamento com platibanda simples.

Conforme Costi e Ribeiro (2003), inicialmente a gleba possuía diversas vertentes de água, que foram drenadas em direção ao ponto mais baixo do terreno, onde se formou um açude em sua porção posterior. Esses movimentos de terra ocorreram para dar espaço para a edificação dos prédios fabris. Não se sabe ao certo o porquê de os prédios terem sido construídos apenas na porção frontal do terreno, mas acredita-se que isso tenha relação com o fluxo das linhas de produção, de entrada e saída de mercadorias, que era facilitado pela proximidade da fábrica à Avenida Mauá.
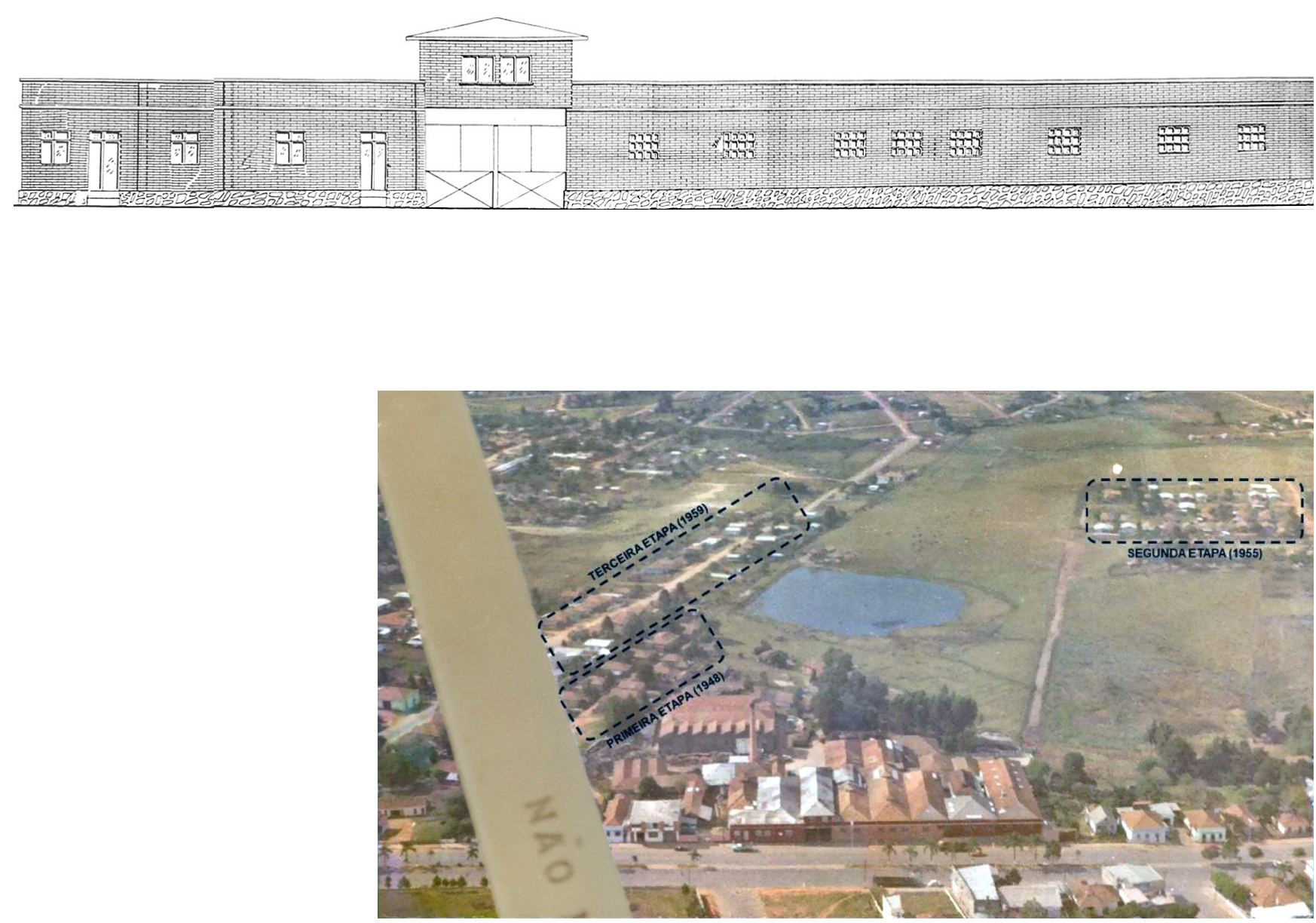


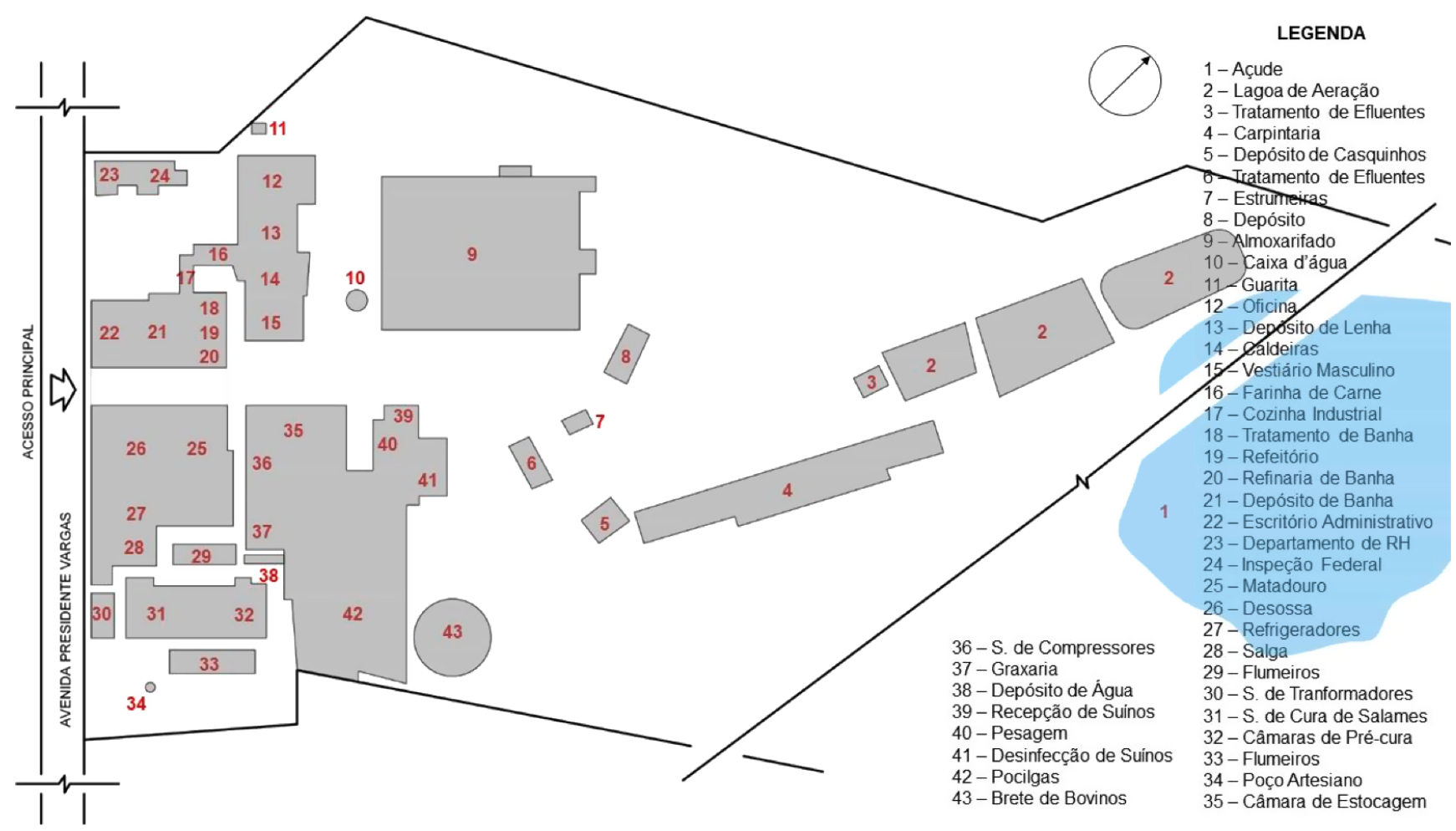

Figura 4: Esquema de implantação do Frigorífico Z. D. Costi (sem escala). Fonte: elaboração própria com base nas plantas levantadas no Arquivo Histórico Regional de Passo Fundo (2018).

4Foi mantida a mesma ordem de numeração encontrada na planta original.
Ademais, tanto os prédios fabris, quanto os conjuntos de moradias, foram sendo construídos conforme se dava o crescimento da produção e a expansão do complexo frigorífico em Passo Fundo e região. Sendo assim, os setores do terreno não ocupados possibilitavam o aumento da capacidade instalada da fábrica e a construção de novos agrupamentos residenciais, quando necessário.

De acordo com a prancha de implantação do complexo, o terreno no qual foi construído o Frigorífico tinha uma área total de $241.628,19 \mathrm{~m}^{2}$. Porém, os prédios fabris ocupavam apenas parte dessa área, em torno de $70.000 \mathrm{~m}^{2}$ (30\%). Mais especificamente, observa-se que a porção frontal do terreno concentrava o setor administrativo (22) ${ }^{4}$, o refeitório (19), as alas destinadas à produção de banha (20/21), o matadouro (25), a sala de desossa (26), a salga (28) e os refrigeradores (27). Nas proximidades do pavilhão principal foi construída a cozinha industrial (17), a sala de oficina (12), o depósito de lenha (13), as caldeiras (14) e o vestiário (15). Na porção oeste do pavilhão principal, foram construídos o departamento de Recursos Humanos (23) e o departamento de Inspeção Federal (24), além de uma guarita de segurança (11). A leste estavam localizados os transformadores (30), o poço artesiano (34) e as salas destinadas à cura de salames e de outros embutidos (31/32). Já, na parte posterior do pavilhão principal foram dispostos o almoxarifado (9), a caixa d'água (10), a sala para desinfecção dos suínos (41), o setor de pesagem (39/40), os compressores (36), a câmara de estocagem (35), entre outras espaços de serviço. Por fim, mais próximo ao açude, nos fundos da gleba, ficava o setor de carpintaria (4), de tratamento de efluentes (3) e as três lagoas de aeração (2) (Figura 4). 
Retifica-se que os prédios foram sendo edificados conforme ia aumentando a produção e o porte da fábrica, resultando em uma disposição que não seguia um padrão regular das construções. Apesar de as edificações estarem isoladas uma das outras e sem um zoneamento bem definido, a sua disposição seguia a lógica formal da linha de produção, iniciando com o setor administrativo e a recepção dos animais, passando pelo setor de desinfecção, abate e desossa, seguindo para os setores de produção de carnes e banha, e finando nas câmaras de estocagem.

Matérias publicadas nos jornais locais da época demonstram que os principais produtos fabricados e comercializados pelo frigorífico eram: banha de porco; congelados de suínos; presuntos cozidos; salames; copas; subprodutos para alimentação animal; couro curtido; e carnes frescas, todos registrados com o slogan da marca Deliciosa. As mercadorias da "Organização Z. D. Costi", além de serem muito populares em Passo Fundo e na região noroeste gaúcha, eram amplamente distribuídas nos principais centros consumidores do Brasil, como em São Paulo e Rio de Janeiro, e também exportadas para outros países, a exemplo dos Estados Unidos, Chile, Grécia e Bélgica (MENÇÃO...,1979).

Para além das contribuições para a consolidação do bairro São Cristóvão e para a economia passo-fundense, o Frigorífico também contribuiu consideravelmente para a dimensão social e para a cultura da cidade. Nesse sentido, vale ressaltar que a diretoria do Z. D. Costi realizava festas para os operários do Frigorífico no Clube Industrial, um dos mais antigos da cidade, bem como nos espaços públicos de Passo Fundo. Tratavam-se de churrascos, desfiles comemorativos, palestras e comemorações religiosas que eram oferecidas ao longo do ano, sobremaneira, nos feriados. Eram eventos que mobilizavam não somente os funcionários da empresa e suas famílias, mas também, a população de uma maneira geral, sobretudo quando ocorriam nos espaços públicos da cidade, como era o caso das comemorações do Dia do Trabalho. Havia, também, uma equipe desportiva chamada Grêmio Esportivo Costi, que participava de torneios de futebol na região (COSTI; RIBEIRO, 2003).

Mais de 1.000 funcionários foram empregados pelo Frigorífico Z. D. Costi no ápice de sua produção, que ocorreu na década de 1970. O encerramento das atividades da fábrica se deu 45 anos após a sua inauguração, no ano de 1993, quando também se deu início ao processo de desmonte da sua vila operária. Em 2014, toda a massa falida da empresa, inclusive as casas, foi demolida e deu lugar às obras do mais novo shopping center da região, o Passo Fundo Shopping (DINIZ; ALMEIDA, 2017). Quanto aos motivos da falência, a política econômica inflacionária daquele período foi uma das principais causas. Tedesco et al. (2005) colocam, também, a diminuição do consumo de banha em detrimento ao óleo de soja ao longo da década de 1980, como fator fundamental para tanto. Destacam, ainda, o papel preponderante das modificações das regras sanitárias e problemas internos de gestão como motivos que culminaram na decadência da fábrica.

O fato de a cidade ter se desenvolvido em direção ao bairro São Cristóvão também dificultou as atividades fabris. Conforme F2 (2018), que trabalhou no setor de abate e desossa entre os anos de 1973 e 1993, e viveu em unidade pertencente à segunda etapa da vila operária, o mau cheiro proveniente da produção passou a incomodar os moradores locais, que começaram a solicitar providências à administração pública em relação ao 
5 Conversa informal com o funcionário $\mathrm{F} 2$, realizada pelo autor. Passo Fundo, out. 2018. funcionamento da fábrica. Além disso, por mais que houvesse equipamentos para o tratamento de efluentes e lagoas de aeração, conforme observado na implantação do empreendimento, os rejeitos derivados da sua produção acabaram poluindo o Arroio Santo Antônio, existente no local; que também culminou em reivindicações populares (informação verbal) ${ }^{5}$.

Desse modo, como anteriormente citado, entraves jurídicos, aspectos econômicos, mudança no contexto produtivo, questões ambientais e relacionadas ao conforto da população tornaram as atividades fabris insustentáveis e culminaram no encerramento das atividades do Frigorífico Z. D. Costi. Outras indústrias do mesmo ramo instaladas na região, de característica familiar, também não conseguiram acompanhar o processo de modernização da produção alimentícia e, aos moldes do caso estudado, entraram em crise e decretaram falência nas décadas de 1980 e 1990, como é o caso do Frigorífico Sarandi S/A e do Frigorífico Planaltina S/A (TEDESCO et al. 2005).

\section{Vila Z. D. Costi: aspectos urbanos e arquitetônicos}

A primeira etapa da Vila Z. D. Costi foi construída ao lado esquerdo do Frigorífico e ficou conhecida à época - final da década de 1940 -, como "Beco Costi". Anos mais tarde, conforme mencionado por Costi e Ribeiro (2003) e por Tedesco e Souza (2016), a segunda etapa foi construída, implantada em lotes urbanizados do lado direito da empresa, próximo à Rua Camilo Ribeiro (Figura 5):

Foram construídos dois conjuntos de casas para operários feitos pelos marceneiros da fábrica: um, em lotes urbanizados sem área de convívio coletivo, exigindo do trabalhador uma caminhada mais longa até o trabalho [segunda etapa]; o outro, mais antigo, cujo acesso era e continua sendo entre duas casas de alvenaria - chamado Beco do Costi pelos moradores do bairro - localizado bem próximo à fábrica [...]. (COSTI; RIBEIRO, 2003, p.09, grifo nosso)

A terceira etapa da Vila Z. D. Costi também foi construída em terreno localizado à esquerda do Frigorífico, em torno de uma via principal que foi denominada de Rua Leopoldo Vila Nova; nomenclatura mantida até os dias atuais. É importante mencionar que esta terceira etapa não foi sequer citada por nenhum dos autores que abordaram o processo de formação e transformação da cidade, do Bairro São Cristóvão, ou a história da Família Costi e dos frigoríficos em Passo Fundo e região. A sua identificação só foi possível por meio dos levantamentos documentais realizados, nos quais foi encontrado o Ato de Aprovação e a planta baixa do empreendimento, datados de 16 de junho de 1959. Por esta razão, considera-se que a vila operária neste artigo estudada foi concebida em três etapas, entre os anos 1948 e 1959, em terrenos situados à esquerda e aos fundos do Frigorífico Z. D. Costi (Figura 5).

As plantas do chamado "Beco Costi" (Figura 6) revelam que a primeira etapa da vila foi construída de maneira mais improvisada, provavelmente em caráter imediatista e emergencial, para abrigar os primeiros funcionários do frigorífico que chegaram em Passo Fundo, ainda durante a construção dos prédios fabris. Mais precisamente, essa etapa consistia em um agrupamento de 20 casas dispostas em ambos os lados de uma ruela estreita, sem saída e sem pavimentação, com 


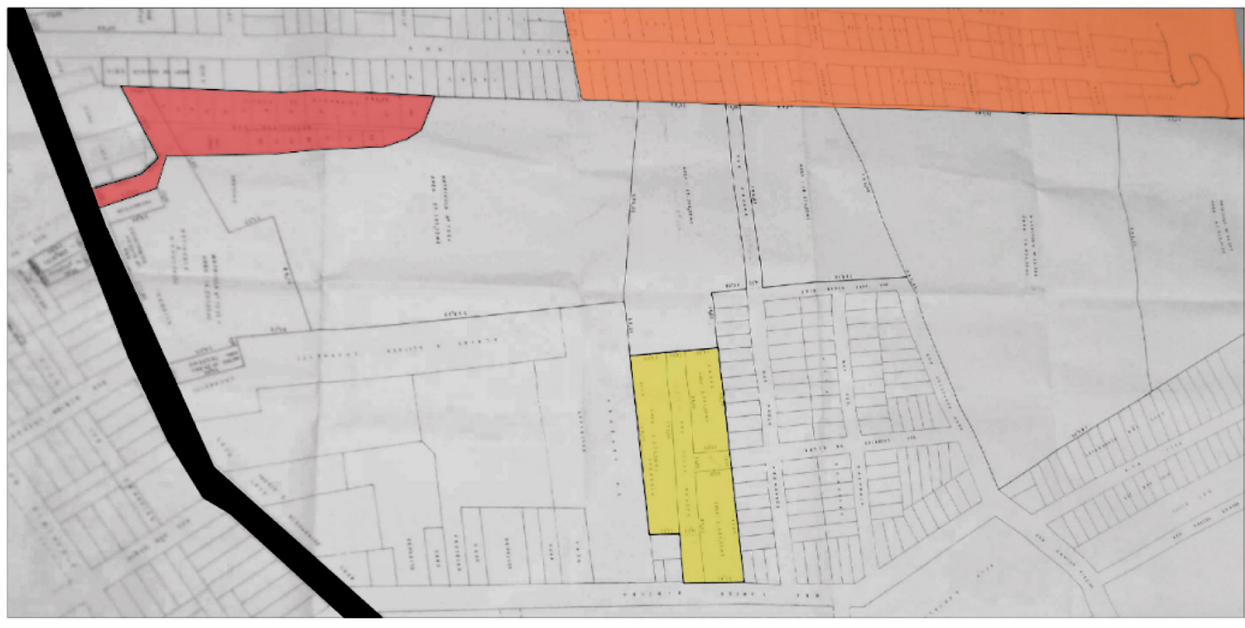

LOCALIZAÇÃO DAS TRÊS PARTES DA VILA OPERÁRIA Z. D. COSTI Sem Escala

Legenda:

\begin{tabular}{l|l|l|l} 
Avenida & Vila Operária & Vila Operária & Vila Operária \\
Presidente Vargas & Beco Costi & Rua Camilo Ribeiro & Rua Leopoldo Vilnova
\end{tabular}

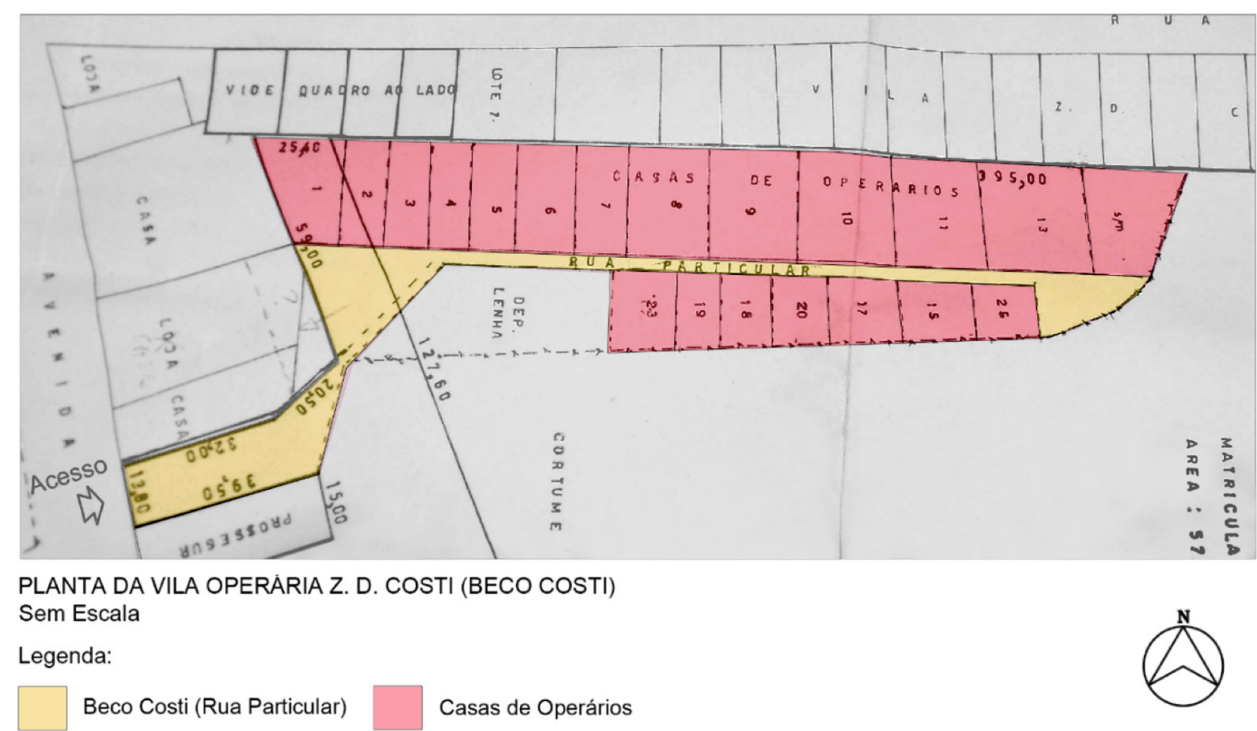

Figura 5 (topo): Planta de situação e localização das três etapas da Vila Operária Z. D. Costi (s/d). Fonte: Arquivo Histórico Regional de Passo Fundo (2018); manipulado pelo autor.

Figura 6 (embaixo): Planta da primeira etapa da Vila Z. D. Costi - "Beco Costi" (s/d). Fonte: Arquivo Histórico Regional de Passo Fundo, manipulação própria (2018). acesso pela mencionada Avenida Mauá. Essa ruela está identificada nos registros originais do empreendimento como Rua Particular e possuía largura de apenas 3,15 $\mathrm{m}$ na sua maior extensão. As áreas dos lotes variavam em formato e dimensão, sendo os de número 13 e 26 o maior e o menor, respectivamente. A planta encontrada nos arquivos não possui identificação das áreas de cada lote, mas pode-se observar que, proporcionalmente, o lote 26 era quatro vezes menor do que lote 13. A largura da via, associada à dimensão dos lotes, pode sugerir um sistema hierárquico, considerando o cargo ocupado pelo trabalhador na fábrica, como especificado pela historiografia especificada. 

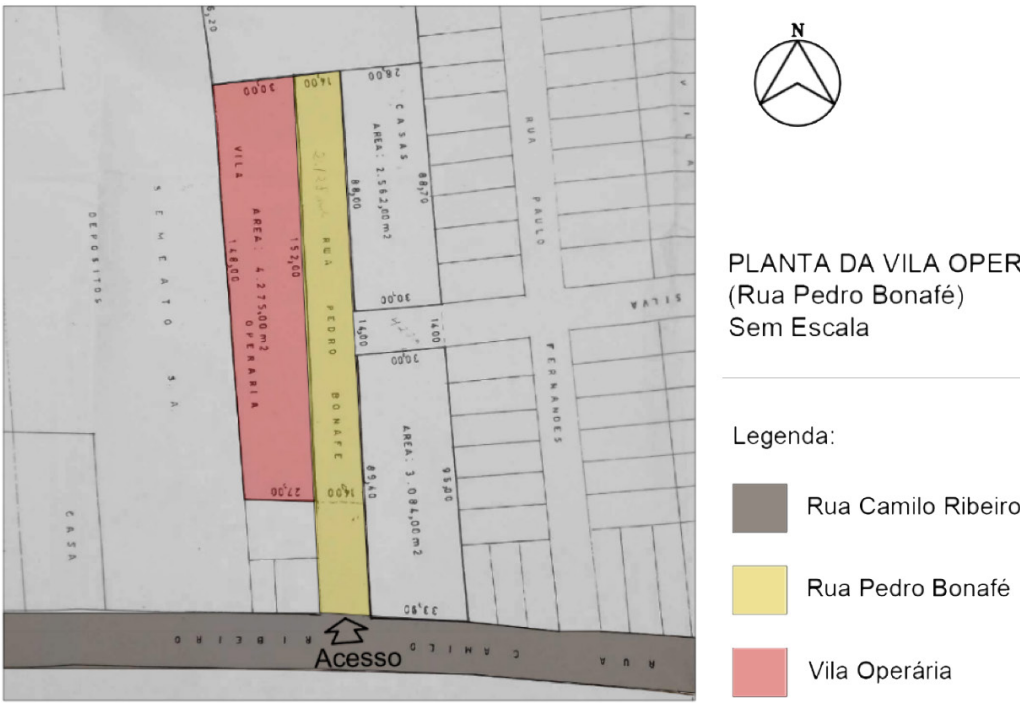

Figura 7: Planta da segunda etapa da Vila Operária Z. D. Costi - Rua Pedro Bonafé (s/d). Fonte: Arquivo Histórico Regional de Passo Fundo, manipulação própria (2018)
A segunda etapa da Vila Z. D. Costi, construída em meados da década de 1950, foi identificada em uma área aos fundos da fábrica, à direita da gleba principal. Ao se analisar a planta (Figura 7), verifica-se que o acesso principal se dava por meio da Rua Camilo Ribeiro, tal como descrito por Tedesco e Souza (2016). Todavia, o terreno onde as casas foram implantadas se localizava, na verdade, na Rua Pedro Bonafé, que possuía ligação com a referida Rua Camilo Ribeiro, mas terminava sem saída, assim como no caso anterior, mantendo a lógica de implantação de vilas operárias especificada na bibliografia analisada.

Percebe-se que essa parte da vila era mais bem estruturada, uma vez que foi concebida em uma segunda etapa. Nesse caso, manteve-se a largura de $14 \mathrm{~m}$ da via em todo o seu comprimento. A área total do terreno onde foram edificadas as habitações operárias era de $4.275 \mathrm{~m}^{2}$. Entretanto, na planta não consta de que maneira essa área foi ocupada pelas edificações, nem há a especificação dos seus recuos, impossibilitando também a identificação exata do número de residências. Por outro lado, conforme os relatos dos funcionários, bem como especificado por Tedesco e Souza (2016), o número total de habitações construídas nas duas primeiras etapas da Vila Z. D. Costi era de 40 unidades. Considerando o número de lotes do chamado "Beco Costi", pode-se inferir que a segunda etapa da vila também possuía em torno de 20 casas, com terrenos de, aproximadamente, $200 \mathrm{~m}^{2}$ cada.

No final da década de 1950, começou a ser construída a terceira, a maior e a mais bem estruturada etapa da vila: um loteamento com 76 terrenos, distribuídos em 10 quadras ao longo de uma via principal que foi denominada Rua Leopoldo Vila Nova. Diferentemente das etapas anteriores, esse loteamento não era de propriedade da Família Costi, mas sim de um investidor, identificado como André Rebecchi. Vale mencionar que, além dos donos de fábricas, a prática da construção de vilas operárias por investidores, chamados de rentistas, era muito comum à época (TIMM, 2015). Em Passo Fundo, diversos outros agrupamentos habitacionais operários foram construídos dessa forma, 
Figura 8: Planta da terceira etapa da Vila Operária Z. D. Costi - Rua Leopoldo Vilanova (1959) - Sem escala. Fonte: Arquivo Histórico Regional de Passo Fundo, manipulação própria (2018). sobretudo a partir dos anos de 1950, período em que a cidade passou por um processo de significativa expansão horizontal graças a abertura de mais de 100 loteamentos desse tipo (FERRETTO, 2012).

A gleba utilizada para a construção da terceira etapa da Vila Z. D. Costi tinha uma área total de $52.928,31 \mathrm{~m}^{2}$ (Figura 8). Destes, $33.624,31 \mathrm{~m}^{2}$ (63.5\%) foram destinados aos 76 lotes residenciais, $14.011,17 \mathrm{~m}^{2}$ (26.5\%) foram incorporadas ao patrimônio municipal pelas ruas, e $5.292,83 \mathrm{~m}^{2}$ (10\% da área total) conformaram a área pública obrigatória. Cabe destacar que não há um projeto paisagístico ou a indicação de nenhum tipo de uso para essa área pública (PASSO FUNDO, 1959).

O eixo estruturador do loteamento, conformado pela Rua Leopoldo Vila Nova, foi projetado com 16m de largura, enquanto as vias transversais (Rua Bahia, Rua Pernambuco, Rua Santa Catarina, Rua Paraná e Rua Rio de Janeiro) possuíam larguras de 12 a 14 metros. Quanto aos terrenos, observa-se que os lotes apresentavam diferentes tipologias e dimensões, variando de $360 \mathrm{~m}^{2}(12 \mathrm{~m} \times 30 \mathrm{~m})$ até lotes com mais de $1.000 \mathrm{~m}^{2}$, como é o caso dos terrenos $A$ e $B$, próximos da área pública, e do terreno de $n^{\circ} 4$ (quadra 8). É provável que esses lotes tenham sido pensados para o uso comercial/serviço, ou para residências maiores de famílias mais abastadas, seguindo mencionado sistema de hierarquização fabril.

Como visto anteriormente, a terceira etapa da vila em questão foi construída com investimentos de André Rebecchi, como consta no ato de aprovação e na planta do empreendimento. Nesse sentido, acredita-se que, aos moldes do que ocorria em diversas outras cidades e diante do crescimento do Frigorífico ao longo da década de 1950, o mencionado rentista decidiu construir a terceira etapa da vila ao lado da fábrica, utilizandose, inclusive, do nome Z. D. Costi para denominar o seu loteamento. Entretanto, vale ressaltar que os lotes construídos por Rebecchi não eram destinados exclusivamente aos funcionários do matadouro, e as casas ali construídas pertenciam aos seus moradores e não possuíam um projeto padrão. Por outro lado, nas duas primeiras etapas, tanto os terrenos quanto as casas eram de propriedade do frigorífico, e existia um projeto padrão para as habitações.

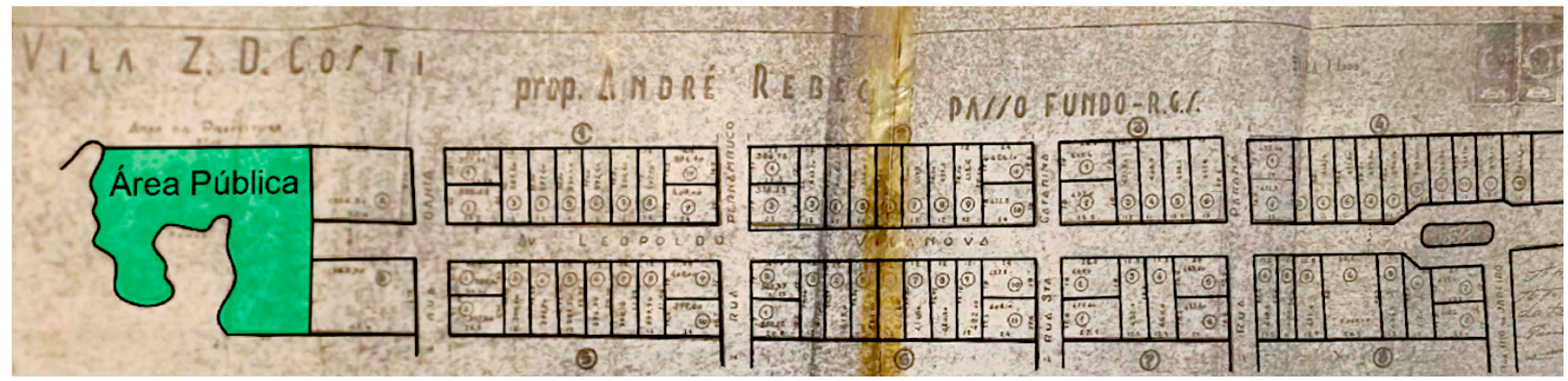


6Conversa informal com o funcionário $\mathrm{F} 1$, realizada pelo autor. Passo Fundo, out. 2018.

7 Conversa informal com o funcionário $\mathrm{F} 1$, realizada pelo autor. Passo Fundo, out. 2018.

Figura 9: casas da primeira (à esquerda) e segunda (à direita) etapas da Vila Z. D. Costi (2003). Fonte: Costi e Ribeiro (2003, p.10).
Como visto anteriormente, o local onde foi construído o Frigorífico Z. D. Costi e sua vila operária era um descampado e a então chamada Avenida Mauá ainda estava sendo estruturada. Corroborando com essas informações, F1 (2018) relatou que, nos primeiros anos de funcionamento da fábrica, a localidade contava apenas com o armazém de secos e molhados da família Lazaretti, algumas residências, a Capela Santo Antônio e um campo de futebol por eles mesmos construído. Não havia nenhum outro equipamento social ou de lazer dentro ou perto da referida vila (informação verbal) ${ }^{6}$. Por outro lado, conforme Costi e Ribeiro (2003), havia um ambulatório disponível para os funcionários e seus familiares, construído nas dependências do próprio frigorífico.

Desse modo, é importante destacar que havia, à época, a necessidade de locomoção dos funcionários da fábrica e suas famílias até o centro de Passo Fundo para acessar os estabelecimentos comerciais e de serviço mais essenciais, tais como mercados, lojas de roupa, bancos, correios, etc. Para tanto, F1 (2018) destacou que alguns veículos de uso coletivo estavam à disposição dos operários, a exemplo do ônibus da empresa Morbini, que fazia o trajeto da fábrica, e de suas proximidades, ao centro de Passo Fundo a cada duas horas (informação verbal) ${ }^{7}$.

\section{As residências operárias do frigorífico}

Na planta do "Beco Costi", algumas informações a respeito das características e materiais das residências do Frigorífico Z. D. Costi foram encontradas (Figura 9). Mais precisamente, as casas possuíam dimensões médias de $7 \mathrm{~m} \times 15 \mathrm{~m}\left(105 \mathrm{~m}^{2}\right)$, as fundações e pilares eram construídos com alvenaria de tijolos maciços, enquanto as paredes externas e internas, as esquadrias e a estrutura dos telhados e pisos, eram de madeira. A pintura era feita com tinta óleo e cal, as entradas de energia eram bifásicas, os encanamentos aparentes e havia fossa séptica.

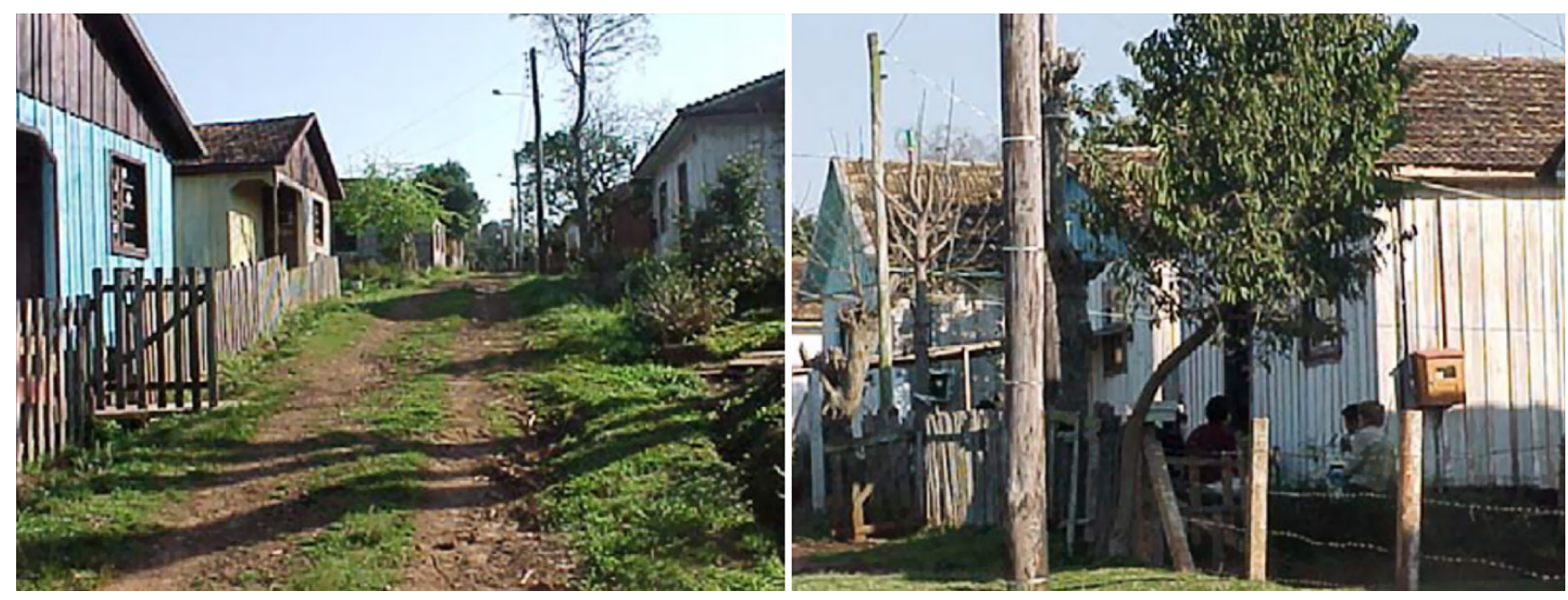


Figura 10: Esquema da fachada das residências da Vila Operária Z. D. Costi. Fonte: elaboração própria com base nas fotografias de Costi e Ribeiro (2003, p.10).

8 Não se encontrou nenhuma planta do projeto arquitetônico das casas, dificultando maiores análises como a distribuição espacial dos cômodos e suas dimensões.

${ }^{9}$ Conversa informal com o funcionário F1, realizada pelo autor. Passo Fundo, out. 2018.

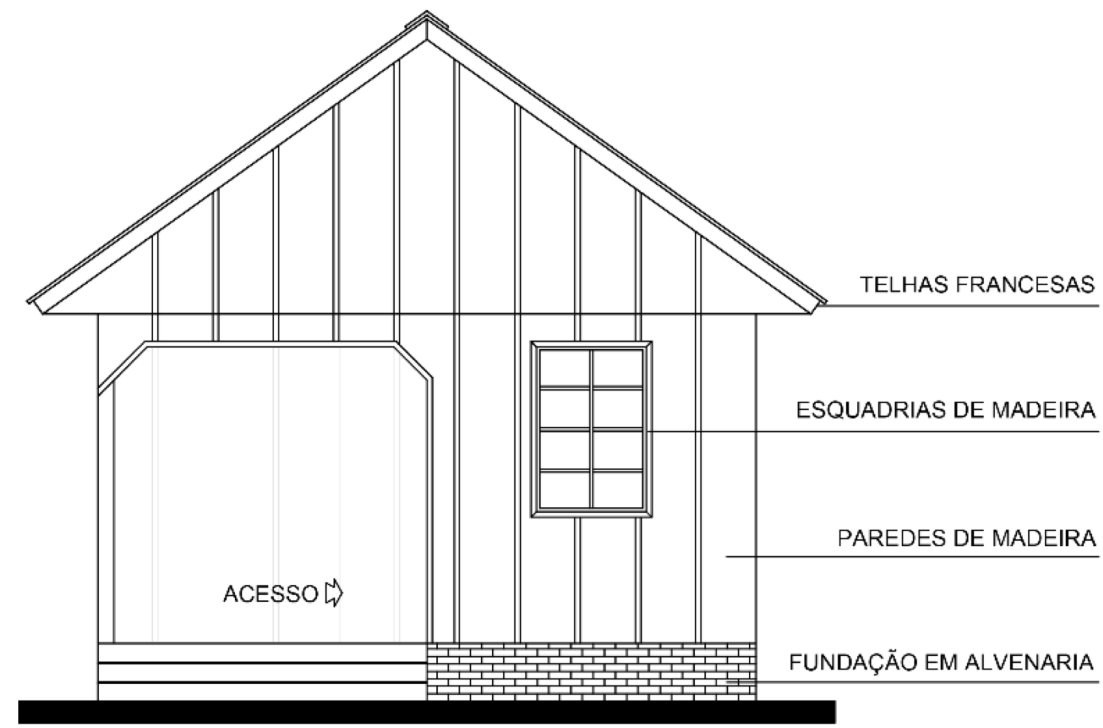

Também foi possível identificar algumas informações acerca de melhoramentos que estavam sendo realizados nas unidades habitacionais do Beco Costi, como a construção de coberturas para servir como garagem e a anexação de banheiros em alvenaria ao corpo da residência ${ }^{8}$. Em linhas gerais, as casas do Frigorífico Z. D. Costi eram muito simples e sem ornamentos, possuíam paredes duplas de madeira com fiação elétrica exposta, e cobertura em duas águas com revestimento de telhas francesas (COSTI e RIBEIRO, 2003) (Figura 10).

O quarto do casal e a sala estavam situados na porção frontal da planta e, em alguns casos, existia uma pequena varanda demarcando a entrada principal. Os outros dois quartos menores e a cozinha ficavam situados aos fundos. A cozinha se conformava como o principal ambiente da casa, onde a família e amigos se reuniam, as crianças faziam os temas e a vida familiar ocorria junto ao fogão à lenha, especialmente no inverno. Inicialmente, de acordo com F1 (2018), havia apenas uma latrina, os sanitários foram anexados às casas com o passar dos anos. As plantas originais das residências não previam garagem no programa de necessidades, que foram sendo construídas conforme os operários foram adquiridos veículos particulares (informação verbal) ${ }^{9}$.

Desse modo, pode-se dizer que, quanto à espacialidade dos cômodos, verifica-se uma similaridade com o padrão organizacional das casas operárias edificadas no período do Brasil Colônia, se distanciando dos modelos empreendidos em meados do século XX, remetendo às diretrizes arquitetônicas modernas. Em relação à tipologia construtiva, observa-se uma semelhança com o "modelo" comumente conhecido como chalé do tipo porta e janela e, para as unidades com varanda frontal, percebese uma aproximação com os bangalôs, ambas remetendo ao início do século XX (ALMEIDA, 2012). 
${ }^{10}$ Conversa informal com o funcionário F3, realizada pelo autor. Passo Fundo, out. 2018.
F3 (2018), que também trabalhou no setor de desossa e residiu em residência da primeira etapa da vila operária entre os anos 1987 e 1992, destacou que todas as residências possuíam pátio aos fundos, utilizados para o cultivo de horta particular. Segundo ele, a relação com a vizinhança era muito boa, e os funcionários se consideravam como pertencentes a uma grande família e se ajudavam na plantação de frutas e verduras. Ademais, registrou que as casas eram confortáveis e grandes, mas um pouco quentes no verão em virtude da madeira (informação verbal) ${ }^{10}$.

Tedesco et al. (2005) consideram que, à época, as casas analisadas promoveram grande inovação regional. Contudo, ao analisar suas características arquitetônicas, pode-se dizer que a inovação trazida pela Família Costi no que diz respeito à construção de suas casas foi menos expressiva e teve influência local. Na década de 1950, conforme colocado por Almeida (2012), grande parte dos agrupamentos habitacionais criados por fábricas no Brasil era, em linhas gerais, mais bem estruturada: a Vila Z. D. Costi não possuía equipamentos de uso coletivo e as residências foram projetadas sem banheiro em um primeiro momento, algo incomum à época. Ademais, destaca-se que a construção das casas, que eram "emprestadas" aos funcionários, traduz o interesse dos donos do frigorífico acerca dos mais variados aspectos da vida de seus funcionários, produzindo relações sociais importantes, tais como o controle vertical do operariado pelo capital e a manutenção da força de trabalho nas proximidades.

Em se tratando da legislação construtiva à época, no ano de 1950, de acordo com o Código de Posturas vigente (Lei $n^{\circ} 164$ de 1950), a cidade de Passo Fundo era dividida em três grandes zonas: Zona 1 - Urbana, que compreendia toda a área calçada da cidade; Zona 2 - Urbana, conformada pelas ruas da cidade em processo de pavimentação, que já apresentasse nivelamento, cordões de calçadas e/ou que estivesse situada até um quarteirão da primeira zona, independente das condições de urbanização; e Zona 3 - Suburbana, que representava os arrabaldes da cidade (PASSO FUNDO, 1950).

Considerando que naquele período a região do Frigorífico Z. D. Costi era um descampado afastado do centro tradicional e comercial de Passo Fundo, pode-se afirmar que área em que a vila operária estudada nesse artigo começou a ser construída pertencia à Zona 3 - Suburbana. Para esses casos, o Código de Posturas possuía apenas três definições: eram permitidas construções em madeira ou alvenaria, implantadas com recuos frontal e lateral de, no mínimo, 2,0 e 1,5 metros, respectivamente; as construções sem aberturas para o terreno adjacente deveriam estar implantadas de modo a não invadir o plano vertical situado entre os lotes; e não eram permitidas construções de habitações, nem edificações comerciais e/ou industriais, caso a gleba em questão pertencesse à Zona 3 e não fosse loteada (PASSO FUNDO, 1950).

Sendo assim, por mais que os projetos arquitetônicos não estejam disponíveis, acreditase que as duas primeiras etapas da vila, que possuíam habitações padronizadas e pertenciam aos proprietários do frigorífico, estavam de acordo com o Código de Posturas em vigor, tendo em vista que a gleba era loteada e havia recuos frontais e laterais mínimos entre as casas. Por fim, considerando que foi possível encontrar as plantas do loteamento, bem como seu ato de aprovação, pode-se afirmar que a terceira etapa, construída por André Rebecchi em 1959, também estava de acordo com as leis municipais. 


\section{Considerações finais}

Em linhas gerais, a instalação de fábricas, de fins do século XIX ao longo da primeira metade do século XX, contribuiu para a transformação das dinâmicas socioeconômicas e do traçado urbano de nossas cidades. Em alguns casos, é possível atrelar até mesmo surgimento de cidades inteiras à construção de conjuntos habitacionais operários, a exemplo do referido núcleo fabril da Companhia Melhoramentos S/A, que deu origem ao município de Caieiras (SP), na década de 1950. Tal processo, salvo as devidas proporções, também é percebido em Passo Fundo, no que diz respeito ao Frigorífico Z. D. Costi, sua vila operária e o bairro São Cristóvão.

A implantação do frigorífico e sua vila operária no sudeste da cidade, às margens da então Avenida Mauá, se deu concomitante ao processo de expansão horizontal da malha urbana de Passo Fundo, iniciado nos anos 1950, e à criação do Plano de Ordenamento e Expansão de 1953, que definiu o bairro São Cristóvão como um dos vetores de crescimento da cidade. Desse modo, por ter sido a primeira grande fábrica da localidade, o Frigorífico Z. D. Costi possibilitou a instalação de novos moradores e inaugurou a vocação industrial do bairro São Cristóvão, que passou a concentrar grande parte das fábricas de Passo Fundo nas décadas seguintes, a exemplo do Frigorífico Planaltina, da Semeato, da Pepsi Cola e da fábrica de refrigerantes Irmãos Bernardon. Com a criação destas fábricas, conjuntos habitacionais operários e benfeitorias resultantes, como a abertura e/ou alargamento de vias, extensão de linhas de transporte público até o local, etc., o bairro passou de periférico no início da década de 1950 para integrado à malha urbana, anos depois.

A grande maioria dos operários que estavam chegando à cidade precisavam aprender o novo ofício e não possuía local para morar ou carro para percorrer grandes distâncias. Desse modo, semelhante às práticas observadas em inúmeras outras cidades, a construção da vila operária estudada surgiu como resposta a essas necessidades. Levando em consideração que as casas eram "emprestadas" aos funcionários, destaca-se o sistema de troca de favores, obrigações, ligações familiares e, para além disso, controle da força de trabalho, que se estabelecia na relação operário/patrão. Em outras palavras, a vila do Frigorífico Z. D. Costi proporcionou moradia adequada e higiênica aos operários e suas famílias, sem custos e nas proximidades da empresa, mas também os imputou certa dependência em relação ao empregador, fomentando ambiguidades nas relações trabalhistas, principalmente no que diz respeito à reivindicação de direitos por parte dos funcionários.

Ressalta-se a ausência de equipamentos de uso coletivo e de lazer, comércios e serviços, implicando na constante necessidade de deslocamentos ao centro da cidade por parte dos funcionários e suas famílias, para atender a tais demandas. O programa de necessidades das 40 casas das duas primeiras etapas da vila, pertencentes ao Frigorífico, era composto por três quartos, sala, cozinha e latrina, e fazia referência ao padrão organizacional dos chalés do tipo porta e janela do período do Brasil colônia. Além disso, a ausência de banheiro nessas unidades habitacionais revela certo atraso em relação ao que estava sendo construído para as moradias operárias em grande parte dos centros urbanos do país à época.

Diante do crescimento do Frigorífico e de seu quadro de funcionários, o rentista André Rebecchi loteou a gleba situada à esquerda da fábrica, originando a terceira 
etapa da Vila Z. D. Costi, conformada por 76 lotes. Diferentemente do observado nas etapas anteriores, as casas construídas nesse loteamento pertenciam aos seus moradores, que as construíam conforme suas possibilidades por meio de investimentos próprios e/ou financiamentos. Vale mencionar que, por não pertencer à massa falida do Frigorífico, essa terceira etapa não foi demolida para dar lugar ao já mencionado Passo Fundo Shopping, em 2014. Apesar de mantidas, essas residências se encontram significativamente descaracterizadas devido a reformas subsequentes resultantes, sobretudo, da mudança de vocação deste setor específico do bairro.

Reafirma-se a importância de basear as pesquisas, sobretudo de ordem arquitetônica e urbana, em dados primários, considerando diferentes fontes e atores, como destacado por Almeida (2012). Como apontado neste artigo, alguns dados importantes relacionados à história urbana de Passo Fundo foram e são perpetuados pela historiografia local, sendo apenas sustentados pela história oral, que acabaram não se sustentando perante os dados coletados nos levantamentos de documentos oficiais e periódicos da época, a exemplo da revelação de uma terceira etapa de construção da Vila Z. D. Costi, ainda não mencionada pela historiografia local. Esta, por fim, configura-se como uma importante vertente de investigação futura.

\section{Agradecimentos}

À Coordenaç̧ão de Aperfeiçoamento de Pessoal de Nível Superior (CAPES) e à Fundação Meridional pelas bolsas concedidas.

\section{Referências bibiográficas}

ALMEIDA, Caliane Christie Oliveira de. Habitação social no Nordeste: a atuação das CAPs e dos IAPs (1930-1964). 2012. Tese (Doutorado em Teoria e História da Arquitetura e do Urbanismo) - Instituto de Arquitetura e Urbanismo, Universidade de São Paulo, São Carlos, 2012. doi:10.11606/T.102.2012.tde-12042013-101921. Acesso em: 2020-05-16.

ARQUIVO HISTÓRICO REGIONAL (Passo Fundo, RS). Acervo Z. D. Costi. Passo Fundo, s/d. 6 fotografias.

BLAY, Eva Alternam. Eu não tenho onde morar: vilas operárias na cidade de São Paulo. São Paulo: Nobel, 1985.

BORBA, Sheila Villanova. Notas sobre o papel da indústria na estruturação das áreas urbanas. Ensaios da FEE, Porto Alegre, n 15, 1994.

CHALHOUB, Sidney. Cidade febril: cortiços e epidemias na Corte Imperial. São Paulo: Cia das Letras, 1996.

CORREIA, Telma de Barros. A indústria e o urbano: aglomerações geradas por fábricas no estado de São Paulo. Oculum Ensaios (PUCCAMP), v. 10, p. 29-42, 2013.

Arquitetura e Paisagem Industrial: as vilas operárias no Recife. ESTUDOS UNIVERSITÁRIOS, v. 32, p. 149-173, 2014.

De vila operária a cidade-companhia: as aglomerações criadas por empresas no vocabulário especializado e vernacular. Revista Brasileira de Estudos Urbanos e Regionais, [S.I.], n. 4, p. 83, maio 2001. ISSN 2317-1529. Disponível em: <http://rbeur.anpur.org.br/ rbeur/article/view/59>. Acesso em: 10 maio 2020.

Núcleos fabris e de mineração no Brasil: as experiências pioneiras (1811-1880). Risco Revista de Pesquisa em Arquitetura e Urbanismo (Online), n. 3, p. 15-42, 2006. 
CORREIA, Telma de Barros. Pedra: plano e cotidiano operário no Sertão. Campinas: Papirus, 1998.

COSTI, Marilice; RIBEIRO, Celi Maria Costi. História de um núcleo fabril: Frigorífico Z.D. Costi Cia. Ltda, Passo Fundo RS. Arquitextos, São Paulo, ano 04, n. 043.07, Vitruvius, dez. 2003.

DINIZ, Pedro Henrique Carretta; ALMEIDA, Caliane Christie Oliveira de. Passo Fundo shopping e os reflexos para uma cidade média no noroeste do Rio Grande do Sul. Revista de Arquitetura IMED, Passo Fundo, v. 6, n. 2, p. 149-165, dez. 2017. ISSN 2318-1109. Disponível em: https://seer.imed.edu.br/index.php/arqimed/article/view/2188/1656. Acesso em: 12 set. 2019.

FERRETTO, Diego. Passo Fundo: estruturação urbana de uma cidade média gaúcha. 2012. Dissertação (Mestrado em Planejamento Urbano e Regional) - Faculdade de Arquitetura e Urbanismo, Universidade de São Paulo, São Paulo, 2012. doi:10.11606/D.16.2012.tde17072012-143123. Acesso em: 2020-07-10.

Segregação socioespacial em cidades médias gaúchas: Caxias do Sul, Passo Fundo, Pelotas e Santa Maria. 2018. Tese (Doutorado em Planejamento Urbano e Regional) Faculdade de Arquitetura e Urbanismo, Universidade de São Paulo, São Paulo, 2018. doi:10.11606/T.16.2019.tde-19122018-172558. Acesso em: 2019-09-12.

GOSCH, L. R. M. Passo Fundo, de Saturnino de Brito ao Mercosul - projetos e imagens urbanas. Dissertação (Mestrado em Urbanismo) - Faculdade de Arquitetura e Urbanismo, Universidade Federal do Rio de Janeiro, Rio de Janeiro, 2002.

GUAZZELLI, Bárbara Gonçalves. Ferrovia, trabalho e habitação: Vilas Operárias de Campinas (1883-1919). 2014. Dissertação (Mestrado em Teoria e História da Arquitetura e do Urbanismo) - Instituto de Arquitetura e Urbanismo, Universidade de São Paulo, São Carlos, 2014. doi:10.11606/D.102.2014.tde-19012015-104005. Acesso em: 2018-05-02.

GUNN, Philip; CORREIA, Telma de Barros. A industrialização brasileira e a dimensão geográfica dos estabelecimentos industriais. Revista brasileira de estudos urbanos e regionais, v. 7 , n. 1, p. 17, 2005.

HEREDIA, Vania Beatriz Merlotti. A Construção de Vilas Operárias no Sul do Brasil: O caso de Galópolis. Scripta Nova - Revista Electrônica de Geografia Y Ciencias Sociales, Agosto de 2003.

INSTITUTO HISTÓRICO DE PASSO FUNDO (Passo Fundo, RS). Fotografia aérea do Frigorífico Z. D. Costi. Passo Fundo, 1970. 1 fotografia.

JANKE, Neuza Regina. Vilas operárias no Rio Grande do Sul: uma breve reflexão sobre o Bairro da Balsa em Pelotas, Bairro São Cristóvão em Passo Fundo e Galópolis em Caxias do Sul. Dimensões, Espírito Santo, 24, p.320-339, 2009.

Entre os valores do patrão e os da nação, como fica o operário? (O Frigorífico Anglo em Pelotas: 1940-1970). 1999. Dissertação de Mestrado. Pontifícia Universidade Católica do Rio Grande do Sul, 1999.

JERONYMO, Vanice. Arquitetura industrial paulista: análise de iniciativas de preservação. Tese (Doutorado em Pós-Graduação em Arquitetura e Urbanismo) - Instituto de Arquitetura e Urbanismo - USP, 2012.

MENÇÃO empresarial: Z. D. Costi \& Cia. Ltda. O Nacional, dez. de 1979, p.14.

MIRANDA, Adriana Eckert. Planos e projetos de expansão urbana industriais e operários em Porto Alegre (1935-1961). 2013. Tese (doutorado) - Faculdade de Arquitetura. Programa de Pós-Graduação em Planejamento Urbano e Regional, Universidade Federal do Rio grande do Sul, Porto Alegre, 2013.

MOREIRA, Márcio Ricardo Teixeira. A formação de uma vila operária em Itajaí (SC): uma industrialização interrompida. 2002. Dissertação (mestrado) - Centro de Filosofia e Ciências Humanas. Programa de Pós-Graduação em Geografia, Universidade Federal de Santa Catarina, Florianópolis, 2002. 
PARIZZI, Marilda Kirst. Passo Fundo: sua história e evolução. Passo Fundo: Berthier, 1983.

PASSAMANI, Lzandra Hoffmann. Pobreza urbana: as condições de habitação popular no município de Passo Fundo/RS. 2012. 99 f. Dissertação (Mestrado em Serviço Social) - Pontifícia Universidade Católica do Rio Grande do Sul, Porto Alegre, 2012.

PASSO FUNDO, Ato 7/59. Aprova a planta do Loteamento Vila Z. D. Costi. Diário Oficial, Passo Fundo, 1959.

PASSO FUNDO, Lei 164/50. Decreta e promulga o novo código de posturas do município de Passo Fundo. Diário Oficial, Passo Fundo, 1950.

PAULITSCH, Vivian da Silva. Rheingantz: Uma Vila Operaria em Rio Grande - RS. 2003. Dissertação de Mestrado. Universidade Estadual de Campinas, 2003.

RAGO, Margareth. Do Cabaré ao Lar: a utopia da cidade disciplinar: Brasil 1890-1930. Rio de Janeiro: Paz e Terra, 1985.

SAMPAIO, Maria Ruth. A promoção privada de habitação econômica e a arquitetura moderna 1930-1964. São Carlos: RiMa, 2002.

TEDESCO, João Carlos et. al. Agroindústrias, frigoríficos e cooperativismo. Porto Alegre: EST, 2005.

TEDESCO, João Carlos; SOUZA, Sirlei de Fátima. Frigoríficos e olarias em Passo Fundo: dinâmicas industriais em sinergias - 1940 a 1980. Erechim: All Print Varella, 2016.

TIMM, Juliane Aimé. Habitações operárias no Brasil: arquitetura e urbanismo da habitação social na primeira metade do século XX. Dissertação (Mestrado em Arquitetura) - Faculdade de Arquitetura, Universidade Federal do Rio Grande do Sul, Porto Alegre, 2015.

VARON, Conceição. E a história se repete... As vilas operárias e os conjuntos residenciais dos IAPs no Rio de Janeiro. Dissertação de Mestrado em Arquitetura e Urbanismo. São Paulo: FAU-USP, 1998.

VIANNA, Mônica Peixoto. Da edificação ao traçado urbano: a experiência de planejamento regional integrado na CESP. 2012. Tese (Doutorado em Teoria e História da Arquitetura e do Urbanismo) - Instituto de Arquitetura e Urbanismo, Universidade de São Paulo, São Carlos, 2012. Acesso em: 2018-05-02.

VIANNA, Mônica Peixoto. Núcleos residenciais da CESP: o processo de desmonte. 2006. Dissertação (Mestrado em Teoria e História da Arquitetura e do Urbanismo) - Escola de Engenharia de São Carlos, Universidade de São Paulo, São Carlos, 2006. Acesso em: 2018-05-02. 